Article

\title{
Plant Extract Treatments Induce Resistance to Bacterial Spot by Tomato Plants for a Sustainable System
}

\author{
Kamal A. M. Abo-Elyousr ${ }^{1,2, *(\mathbb{C})}$, Najeeb M. Almasoudi ${ }^{1}$ (), Ahmed W. M. Abdelmagid ${ }^{2,3}$, \\ Sergio R. Roberto ${ }^{4, *(D)}$ and Khamis Youssef $5, *$ (D) \\ 1 Department of Arid Land Agriculture, King Abdulaziz University, Jeddah 80208, Saudi Arabia; \\ nalmasoudi@kau.edu.sa \\ 2 Department of Plant Pathology, University of Assiut, Faculty of Agriculture, Assiut 71526, Egypt; \\ Ahmed.Abdelmagid@umanitoba.ca \\ 3 Plant Science Department, Manitoba University, Winnipeg, MB R3T 2N2, Canada \\ 4 Department of Agronomy, Agricultural Research Center, Londrina State University, Londrina, \\ PR 86057-970, Brazil \\ 5 Agricultural Research Center, Plant Pathology Research Institute, 9 Gamaa St., Giza 12619, Egypt \\ * Correspondence: kaaboelyousr@agr.au.edu.eg (K.A.M.A.-E.); sroberto@uel.br (S.R.R.); \\ youssefeladawy@yahoo.com or youssefeladawy@arc.sci.eg (K.Y.)
}

Received: 27 April 2020; Accepted: 19 June 2020; Published: 22 June 2020

\begin{abstract}
The aim of this study is to assess the effect of extracts of Nerium oleander, Eucalyptus chamadulonsis and Citrullus colocynthis against bacterial spot disease of tomato and to investigate the induction of resistance by tomato (Solanum lycopersicum) in order to promote a sustainable management system. The antibacterial activity of aqueous and ethanol plant extracts was tested against Xanthomonas axonopodis pv. vesicatoria, isolate PHYXV3, in vitro and in vivo. The highest antibacterial activity in vitro was obtained with C. colocynthis, N. oleander and E. chamadulonsis, respectively. In vivo, ethanol extracts of $N$. oleander and E. chamadulonsis were more effective than aqueous extracts in reducing pathogen populations on tomato leaves. Under greenhouse conditions, application of the plant extracts at $15 \%(\mathrm{v} / \mathrm{v})$ to tomato plants significantly reduced disease severity and increased the shoot weight of 'Super Marmande' tomato. In most cases, plant extracts significantly increased total phenol and salicylic acid content of tomato plants compared to either healthy or infected ones. In addition, C. colocynthis and E. chamadulonsis extracts significantly increased peroxidase activity while only E. chamadulonsis increased polyphenol oxidase after infection with the causal agent. The results indicated that the plant extracts showed promising antibacterial activity and could be considered an effective tool in integrated management programs for a sustainable system of tomato bacterial spot control.
\end{abstract}

Keywords: Induced resistance; polyphenol oxidase; peroxidase; plant extract; bacterial spot

\section{Introduction}

Worldwide tomato (Solanum lycopersicum) production is 182,256,458 MT with a harvested area around 4762,457 ha [1]. Tomato crops are facing many bacterial diseases including bacterial spot caused by Xanthomonas axonopodis pv. vesicatoria $[2,3]$. The application of copper bactericides, alone or in combination with other pesticides and antibiotics (especially streptomycin), is the primary tool to control such bacterial diseases [4]. However, several limitations have restricted their use including bactericide resistance, market demands related to residues and worries of human health [5]. Thus, safe alternative control methods need to be tested and developed [6-8]. Among the alternative means, 
many studies have proven the antimicrobial activity of various plant species against bacterial spot diseases $[9,10]$. In addition, several studies have screened extracts of various higher plant leaves, fruit and seeds for controlling phytopathogenic bacteria [11,12]. Basically, higher plants are considered to be one of the major sources of bioactive, economically significant natural compounds, pesticides and pharmaceuticals [13].

Numerous studies were mentioned that plant extracts such as Cesalpinia coriaria and essential oils have shown satisfactory antifungal and antibacterial properties in vivo [14,15]. Recently, many higher plant products have attracted the attention of researchers seeking phytochemicals to evaluate for their antimicrobial properties [16-18].

Leaf extracts of several species, e.g., Eucalyptus globules, Datura stramonium, Ocimum spp., Salix spp., Rosmarinus officinalis, Cydonia oblonga and Foeniculum vulgare, have been used successfully to control diverse plant diseases $[12,19,20]$. Application of some chemicals and plant extracts have induced resistance in plants against many causal pathogens including bacteria, fungi, viruses and nematodes [21,22]. In addition, plant extracts have been found to induce a defense response in infected plants [23]. Geetha and Shetty [24] mentioned that the mode of action of plant extracts against bacterial pathogens may enhance natural host defense mechanisms by increasing the activity of some antioxidant enzymes, e.g., peroxidases, polyphenol oxidase or the accumulation of phenolic compounds [25]. This may directly affect the survival of the pathogens or act indirectly on plant metabolism [26]. In addition, polyphenol oxidases (PPOs) catalyze the oxidation of several phenols to o-quinones [27].

The present study aimed to assess the effectiveness of extracts of three plant species against $X$. axonopodis pv. vesicatoria in vitro and the suppression of bacterial spot disease of tomato plants under greenhouse conditions. Furthermore, the potential change of total phenols, salicylic acid content, peroxidase and polyphenoloxidase activity in response to application of the extracts was investigated.

\section{Materials and Methods}

\subsection{Seeds, Growth of Seedlings and Bacterial Isolates}

'Super Marmande' tomato seeds used in this study were kindly provided by the Vegetable Dept. Faculty of Agriculture, Assiut University, Egypt. Pots of $30 \mathrm{~cm}$ diameter and containing sand $(3 \mathrm{~kg} / \mathrm{pot})$ were used to grow two seedlings. The pots were kept on a greenhouse bench at $30 \pm 5{ }^{\circ} \mathrm{C}$ and $68 \%-80 \% \mathrm{RH}$, irrigated as required and fertilized with $30 \mathrm{~mL}$ of $0.01 \mathrm{~g}$ of NPK formulation (12:4:6). Xanthomonas campestris pv. vesicatoria (Doidge) Dye isolate PHYXV3 was provided from the collection of the Department of Plant Pathology, Faculty of Agriculture, Assiut University, Egypt. This isolate was identified, and its pathogenicity was confirmed according to Abo-Elyousr and El-Hendawy [3].

\subsection{Preparation of Leaf Extracts}

Methods described by Abo-Elyousr and Asran [12] were followed to prepare the aqueous and $70 \%$ ethanol extracts. Briefly, $10 \mathrm{~g}$ of fresh leaves of Nerium oleander, Eucalyptus chamadulonsis and Citrullus colocynthis were collected from a private farm belonging to Assiut Governorate and washed several times with distilled water. They were crushed in $100 \mathrm{~mL}$ of sterile water or ethanol $(1: 10 \mathrm{w} / \mathrm{v})$ using a mortar and pestle and filtered through double-layered cheesecloth. The ethanolic filtrate was concentrated by exposition to $60^{\circ} \mathrm{C}$ in a water bath for $30 \mathrm{~min}$ to evaporate ethanol and kept in dark glass bottles. The final extracts were diluted with distilled water to reach a $10 \%$ and $15 \%$ $\mathrm{v} / \mathrm{v}$ concentration. These concentrations were sterilized by $0.2 \mathrm{~m}$ disposable syringe filters and kept in bottles in the dark until used [28].

\subsection{Effect of Plant Extracts on Pathogen Growth In Vitro}

To test the effect of three plant extracts on the growth of the bacterial pathogen, the paper disc diffusion method was used [29]. Sterilized filter paper discs $(5 \mathrm{~mm})$ were placed in Petri plates containing nutrient sucrose agar (NSA) medium and inoculated with $100 \mu \mathrm{L}$ of the bacterial suspension 
of PHYXV3 $\left(5 \times 10^{6} \mathrm{CFU} \mathrm{mL} \mathrm{mL}^{-1}\right)$. Sterilized filter paper discs were moistened with $5 \mu \mathrm{L}$ of each concentration $(10 \%$ and $15 \%)$ of plant extract. As check treatments, water and ethanol served as controls. After $48 \mathrm{~h}$ of incubation at $27^{\circ} \mathrm{C}$, the inhibition zones around the paper disc were measured. Four plates were used for each treatment, as replicates, and the whole trial was repeated twice.

\subsection{Effect of Plant Extracts on Disease Severity and Pathogen Population}

\subsubsection{Preparation of Inoculum and Inoculation Methods}

Inoculum of PHYXV3 was prepared from cultures shaken for $48 \mathrm{~h}$ and incubated at $28 \pm 2{ }^{\circ} \mathrm{C}$ for $48 \mathrm{~h}$. The cultures were centrifuged at $6000 \times \mathrm{g}$ at room temperature for $20 \mathrm{~min}$ and were then suspended in sterile distilled water. The bacterial concentration was photometrically adjusted using a spectrophotometer (Spectronic ${ }^{\circledR} 20$ Genesys, Schutt Labortechnik, Cambridge CB5 8HY, UK) to $5 \times 10^{6} \mathrm{CFU} \mathrm{mL}^{-1}$.

Four-week-old tomato seedlings were inoculated with PHYXV3 by spraying each plant with $20 \mathrm{~mL}$ of the pathogen solution using small hand sprayer. This volume was enough to cover plant leaves with the pathogen solution. Inoculated plants were covered by polyethylene bags for $48 \mathrm{~h}$ at $25-27^{\circ} \mathrm{C}$ in the greenhouse to maintain the humidity and to prevent inoculation desiccation and inoculum establishment on the plant. Two days after inoculation, tomato seedlings were treated with a $15 \% \mathrm{v} / \mathrm{v}$ concentration of each plant extract and were kept under greenhouse conditions. Fourteen days after inoculation, disease severity was recorded based on the scale of Abbasi et al. [30]. Four replicates (two seedlings each) were used per each treatment and greenhouse experiments were repeated twice.

\subsubsection{Determination of Pathogen Population on Tomato Leaves}

The number of colonies of PHYXV3 $\left(5 \times 10^{6} \mathrm{CFU} \mathrm{mL}{ }^{-1}\right)$ was estimated one week after the time the tomato plants were treated with the plant extracts. About $5 \mathrm{~mm}$ of tomato leaf was excised and homogenized in $1 \mathrm{~mL}$ of sterile distilled water. Several dilutions were made and then $0.1 \mathrm{~mL}$ of each dilution was spread on plates containing nutrient sucrose agar (NSA) medium. Petri dishes were incubated for $72 \mathrm{~h}$ at $26^{\circ} \mathrm{C}$, and then recovered colonies were counted. Four replicates were used from each treatment and the results were expressed as CFU/g [3].

\subsubsection{Determination of Fresh and Dry Weight}

At the end of experiment (90 days), the seedlings from each treatment were removed, washed with distilled water to eliminate the soil, blotted with tissue paper, and then dried at $60{ }^{\circ} \mathrm{C}$ for $72 \mathrm{~h}$ when shoot dry weight was recorded.

\subsection{Determination of Total Phenols and Salicylic Acid Contents}

\subsubsection{Preparation of Samples}

Eight leaves were collected from eight seedlings per treatment. One gram of tomato leaves was ground in liquid nitrogen and homogenized in $10 \mathrm{~mL}$ of $80 \%$ methanol, and the homogenate was centrifuged at $10,000 \times g$ for $30 \mathrm{~min}$ at $4{ }^{\circ} \mathrm{C}$. The pellet was discarded after addition of ascorbic acid $\left(0.02 \mathrm{~g} \cdot \mathrm{mL}^{-1}\right)$. A rotary evaporator was used to evaporate the supernatant at $65^{\circ} \mathrm{C}$ and the process was repeated three times, each for $5 \mathrm{~min}$. The residues were dissolved in $5 \mathrm{~mL}$ of $80 \%$ methanol. For each treatment four replicates were used [31].

\subsubsection{Total Phenol Content}

The methods described by Sahinet al. [32] were followed to determine the total phenol content in leaves. Total phenol content was determined by spectrophotometer (Spectronic ${ }^{\circledR} 20$ Genesys, Schutt Labortechnik, Cambridge CB5 $8 \mathrm{HY}, \mathrm{UK}$ ) at $767 \mathrm{~nm}$ as $\mathrm{mg} \cdot \mathrm{g}^{-1}$ plant fresh weight using gallic acid as standard. Total phenol content was expressed as $\mathrm{mg}$ of gallic acid per $\mathrm{g}$ plant material. 


\subsubsection{Salicylic Acid Content}

Salicylic acid (SA) content was estimated using a method modified from Datet al [33]. A $500 \mu \mathrm{L}$ sample of leaf homogenate was mixed with $250 \mu \mathrm{L}$ of $10-\mathrm{N} \mathrm{HCl}$ and $1 \mathrm{~mL}$ of methanol. Samples were incubated in a water bath at $80^{\circ} \mathrm{C}$ for $2 \mathrm{~h}$. One $\mathrm{mL}$ of methanol was added to the mixture and each sample was neutralized with $4-5$ drops of $1-\mathrm{M} \mathrm{NaHCO}_{3}$. The optical density (OD) was measured at $254 \mathrm{~nm}$, and SA content was calculated and expressed as $\mu \mathrm{g}$ of SA per g plant material.

\subsection{Enzymatic Activities}

To determine peroxidase (PO) and polyphenol oxidase (PPO) activities, $1 \mathrm{~g}$ of fresh tomato leaf tissue was homogenized in liquid nitrogen with $10 \mathrm{~mL}$ of 0.1 -M sodium acetate buffer $(\mathrm{pH}$ 5.2) and the mixture was centrifuged at $1000 \times g$ for $30 \mathrm{~min}$ at $4^{\circ} \mathrm{C}$. For each treatment, four replicates were used. Using Bradford reagent, the total protein content of the supernatant was determined [34].

\subsubsection{Peroxidase Activity (PO)}

Activity of peroxidase was determined using guaiacol as a substrate according to the method described by Putter [35]. The reaction mixture was composed of $0.2 \mathrm{~mL}$ supernatant, $1 \mathrm{~mL} 0.1-\mathrm{M}$ sodium acetate buffer ( $\mathrm{pH} 5.2$ ), $0.2 \mathrm{~mL} 1 \% \mathrm{w} / \mathrm{v}$ guaiacol and $0.2 \mathrm{~mL}$ of $1 \% \mathrm{H}_{2} \mathrm{O}_{2}$. The mixture was incubated for $5 \mathrm{~min}$ at $25^{\circ} \mathrm{C}$ then measured at $436 \mathrm{~nm}$ by spectrophotometer (Spectronic ${ }^{\circledR} 20$ Genesys, Schutt Labortechnik, Cambridge CB5 8HY, UK). Peroxidase activity was calculated as the change in absorbance units $(\mathrm{Au})$ and expressed as change in Au per mg protein. Extraction buffer served as a blank reference.

\subsubsection{Polyphenol Oxidase (PPO) Activity}

Polyphenol oxidase activity was determined according to the method described by Batra and Kuhn [36]. The reaction mixture was $0.5 \mathrm{~mL}$ of supernatant, $2 \mathrm{~mL} 50-\mathrm{mM}$ Sorensen phosphate buffer ( $\mathrm{pH}$ 6.5) and $0.5 \mathrm{~mL}$ of the substrate pyrocatechol (10\%, Sigma Aldrich, Missouri, USA). The reaction mixture was incubated in water bath for $2 \mathrm{~h}$ at $37^{\circ} \mathrm{C}$ and measured at $410 \mathrm{~nm}$. The activity of PPO was calculated as OD at $410 \mathrm{~nm}$ and expressed as OD.mg protein ${ }^{-1}$.

\subsection{Statistical Analysis}

All experiments were repeated twice, and percentage data were arcsine transformed before analyses to normalize variance. Data were subjected to one-way analysis of variance (ANOVA) using Statistica Software Ver. 6.0 (Stat Soft, Inc., Tulsa, OK, USA). Fisher's protected least significant difference was used at $p \leq 0.05$ to distinguish the differences among various treatments [37]. When applicable, error bars are shown.

\section{Results and Discussion}

\subsection{Effect of Plant Extracts on Pathogen Growth In Vitro}

The plant extracts had variable effect on the growth of the pathogen in vitro (Figure 1 ). The greatest reduction was obtained with both extracts of $C$. colocynthis at $15 \%$ (ethanol $(0.81 \mathrm{~mm})$ and water (0.65)) followed by the ethanol extract of $N$. oleander (ethanol $(0.59 \mathrm{~mm}$ ) and water $(0.50)$ ), while the least reduction was obtained from E. chamadulonsis (ethanol $(0.44 \mathrm{~mm})$ and water $(0.51)$ ). Overall, the inhibition of pathogen growth increased as the concentration increased from $10 \%$ to $15 \%$. Thus, $15 \%$ was used for further experiments. The results herein agree with those reported by Abo-Elyousr and Asran [12], in which garlic (Allium sativum) extract had a strong antibacterial activity against bacterial wilt in vitro followed by Datura spp and then $N$. oleander. Our previous study reported that gas chromatography mass spectrometry (GC-MS) analysis of the aqueous extract of $C$. colocynthis contained 37 compounds and their derivatives, including imidazole. In addition, Rahman and 
Gray [38] mentioned that dimericcarbazole was the most effective compound against Escherichia coli and Proteus vulgaris, both Gram-negative bacteria.

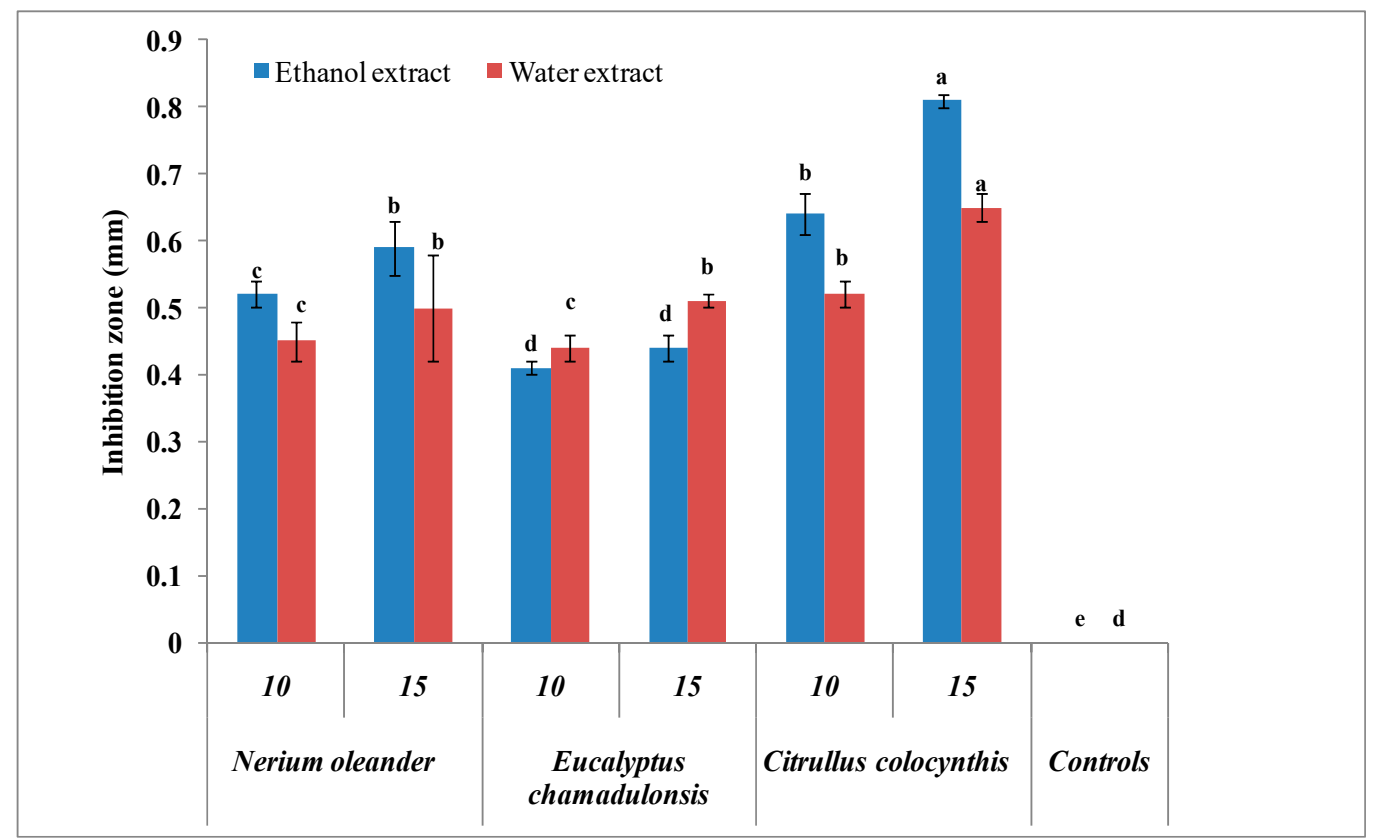

Figure 1. Antibacterial activity of $10 \%$ and $15 \%$ concentrations of plant extracts of Nerium oleander, Eucalyptus chamadulonsis and Citrullus colocynthis against Xanthomonas axonopodis pv. vesicatoria PHYXV3 in vitro after $48 \mathrm{~h}$ of incubation at $27^{\circ} \mathrm{C}$. Four replicate plates were used for each treatment and the experiment was repeated twice. Columns with the same letters are not significantly different according to Fisher's protected least significant difference at $p \leq 0.05$.

\subsection{Determination of Pathogen Population on the Tomato Leaves}

Application of the plant extracts at the $15 \%$ concentration reduced the number of bacteria in tomato leaves compared to the infected control (Table 1). The greatest reduction was achieved by C. colocynthis [ethanol (3.0 CFU/g) and water (4 CFU/g)] followed by ethanol extract of $N$. oleander $(5.0 \mathrm{CFU} / \mathrm{g})$ and E. chamadulonsis $(5.1 \mathrm{CFU} / \mathrm{g})$, with no difference between the latter two. The lowest reduction was with water extracts of E. chamadulonsis $(7.7 \mathrm{CFU} / \mathrm{g}$ ) and Nerium oleander (6.2 CFU/g), respectively, which did not differ. The results assumed that the application of the plant extracts reduced the number of the bacterial pathogens by toxicity within the cytoplasm to the pathogen. These results are in agreement with Draz et al. [39] who revealed the bioactivity of certain components of plant extracts.

Table 1. Effect of $15 \%$ concentrations of water and ethanol plant extracts of Nerium oleander, Eucalyptus chamadulonsis and Citrullus colocynthis on the population of Xanthomonas axonopodis pv. vesicatoria PHYXV3 in 'Super Marmande' tomato leaves after seven days of inoculation.

\begin{tabular}{ccc}
\hline Plant Extracts & Method of Extract & CFU/g \\
\hline \multirow{2}{*}{ Nerium oleander } & Water extract & $6.2 \pm 0.15 \mathrm{~b}^{\mathrm{y}}$ \\
& Ethanol extract & $5.0 \pm 0.72 \mathrm{c}$ \\
Eucalyptus chamadulonsis & Water extract & $7.7 \pm 0.38 \mathrm{~b}$ \\
& Ethanol extract & $5.1 \pm 0.23 \mathrm{c}$ \\
Citrullus colocynthis & Water extract & $4.0 \pm 0.15 \mathrm{~d}$ \\
& Ethanol extract & $3.0 \pm 0.45 \mathrm{~d}$ \\
Controls & Infected & $9.7 \pm 0.53 \mathrm{a}$ \\
& Healthy & $0 \mathrm{e}$ \\
\hline
\end{tabular}

${ }^{\mathrm{z}}$ Bacterial population was recorded one week after inoculation with the isolate PHYXV3 and is expressed as log $10^{8}$ colony forming units (CFU) $\mathrm{g}^{-1}$ leaf tissue. Four replicates were used from each treatment. ${ }^{y}$ Values in the column followed by the same letters are not significantly different according to Fisher's protected least significant difference at $p \leq 0.05$ level. 


\subsection{Effect of Plant Extracts on Disease Severity and Dry Weight of Shoots}

Treatment with extracts of $C$. colocynthis gave the greatest reduction of disease severity, $20.0 \%$ and $21.2 \%$ for ethanol and water extracts, respectively, with no significant difference between them, followed by N. oleander and E. chamadulonsis, respectively (Table 2). Furthermore, C. colocynthis gave the greatest shoot dry weight (44.7 and 43.0 for ethanol and water, respectively), while the other treatments also increased shoot weight compared to the infected control, but without statistical difference between them. These results agree with Hassan et al. [40] who mentioned that the application of certain plant extracts reduced wilt diseases of potato plants and increased the yield s of tubers compared to an infected control. This may be due to the lower numbers of the pathogen in treated plants and the induction of some antioxidant enzymes that can reduce pathogens in the tissues [29]. Similarly, Drazet et al. [39] used five plant extracts (pomegranate (Punica granatum), acalypha (Acalypha wilkesiana), henna (Lawsonia inermis), lantana (Lantana camara) and chinaberry (Melia azedarach) to induce resistance in wheat (Triticum aestivum) against rust disease and all plant extracts reduced disease severity and increased yield components.

Table 2. Disease severity (\%) and shoot dry weight of 'Super Marmande' tomato treated with extracts of Nerium oleander, Eucalyptus chamadulonsis and Citrullus colocynthis after inoculation with Xanthomonas axonopodis pv. vesicatoria PHYXV3.

\begin{tabular}{cccc}
\hline Plant Extracts & Method of Extract & Disease Severity (\%) & Shoot Weight (gm) \\
\hline \multirow{2}{*}{ Nerium oleander } & Water extract & $29.13 \pm 0.10^{\mathrm{z}} \mathrm{c}^{\mathrm{y}}$ & $25.2 \pm 0.30 \mathrm{c}$ \\
& Ethanol extract & $30.00 \pm 1.51 \mathrm{c}$ & $25.5 \pm 0.38 \mathrm{c}$ \\
Eucalyptus chamadulonsis & Water extract & $39.90 \pm 0.68 \mathrm{~b}$ & $26.8 \pm 0.60 \mathrm{c}$ \\
\multirow{2}{*}{ Citrullus colocynthis } & Ethanol extract & $33.13 \pm 0.10 \mathrm{~cd}$ & $24.2 \pm 0.30 \mathrm{c}$ \\
& Water extract & $21.23 \pm 0.17 \mathrm{e}$ & $43.0 \pm 1.51 \mathrm{ab}$ \\
Controls & Ethanol extract & $20.00 \pm 0.76 \mathrm{e}$ & $44.7 \pm 0.45 \mathrm{ab}$ \\
& Infected & $45.23 \pm 0.98 \mathrm{a}$ & $13.2 \pm 0.30 \mathrm{~d}$ \\
& Healthy & $0 \mathrm{f}$ & $45.2 \pm 0.91 \mathrm{a}$ \\
\hline
\end{tabular}

${ }^{\mathrm{z}}$ Mean \pm SE of 4 replicates (two seedlings each) for each treatment. ${ }^{y}$ Values in the columns followed by the same letters are not significantly different according to Fisher's protected least significant difference at $p \leq 0.05$ level.

\subsection{Effect of Plant Extracts on Total Phenol and Salicylic Acid Contents}

Overall, total phenol content was significantly higher in treated versus infected or healthy control plants with the exception of the ethanol extract of $C$. colocynthis. In the present study, treatment with the plant extracts increased the accumulation of phenolic substances in response to pathogen infection (Figure 2). Values of phenol content ranged from 3.13 to $3.57 \mathrm{mg}_{\text {gallic acid }}{ }^{-1}$ for the water extraction method and from 2.81 to $3.74 \mathrm{mg}$ gallic acid $\mathrm{g}^{-1}$ for the ethanol extraction method for the three species. Accumulation of phenolic compounds at the infection site was correlated with the suppression of pathogen development since these compounds are toxic to phytopathogenic bacteria. Resistance maybe also improved by increasing the $\mathrm{pH}$ of the plant cell cytoplasm due to an increase in phenolic acid substances which prevents the development of the pathogen [41].

Salicylic acid (SA) content significantly increased with application of C. colocynthis aqueous $(6.4 \mu \mathrm{g}$ salicylic acid $\left.{ }^{-1}\right)$ and ethanol $\left(6.37 \mu \mathrm{g}\right.$ salicylic acid $\left.\mathrm{g}^{-1}\right)$ extracts after 7 days of treatment, though there was no significance difference between them (Figure 3). The results showed statistically significant increases in SA levels for all treatments versus control. However, it is also clear that ethanolic and aqueous extracts showed similar SA levels for all treatments within species and that $C$. colocynthis extracts induced the largest SA increases among the treatments. De Meyer et al. [42] suggested that SA accumulation is important for expression of several modes of plant disease resistance. In addition, SA mediates plant defense against pathogens, accumulating in both infected and distal leaves in response to pathogen infection [29]. The enhanced SA contents are a prerequisite for expression of systemic acquired resistance against $R$. solanacreaum in potato (Solanum tuberosum) plants [43,44], and these results may also indicate that applied plant extracts induce pathogen resistance in plants either via the 
activation of a signaling pathway that is dependent on SA or via the activation of a novel signaling cascade that is not dependent on SA, jasmonic acid or ethylene signaling.

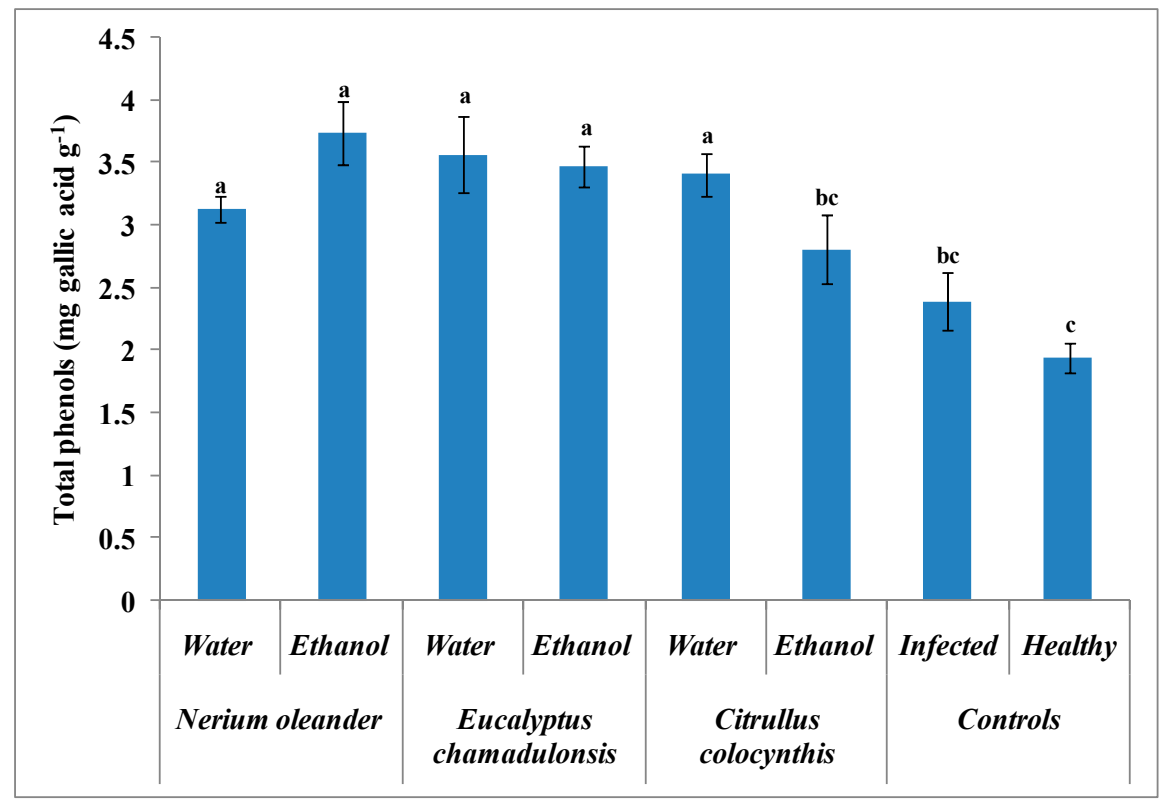

Figure 2. Effect of $15 \%$ concentrations of plant extracts of Nerium oleander, Eucalyptus chamadulonsis and Citrullus colocynthis on total phenols of 'Super Marmande' tomato after 7 days of treatment with the extracts and inoculated with Xanthomonas axonopodis pv. vesicatoria PHYXV3. Four replicates were used for each treatment. Columns with the same letters are not significantly different according to Fisher's protected least significant difference at $p \leq 0.05$.

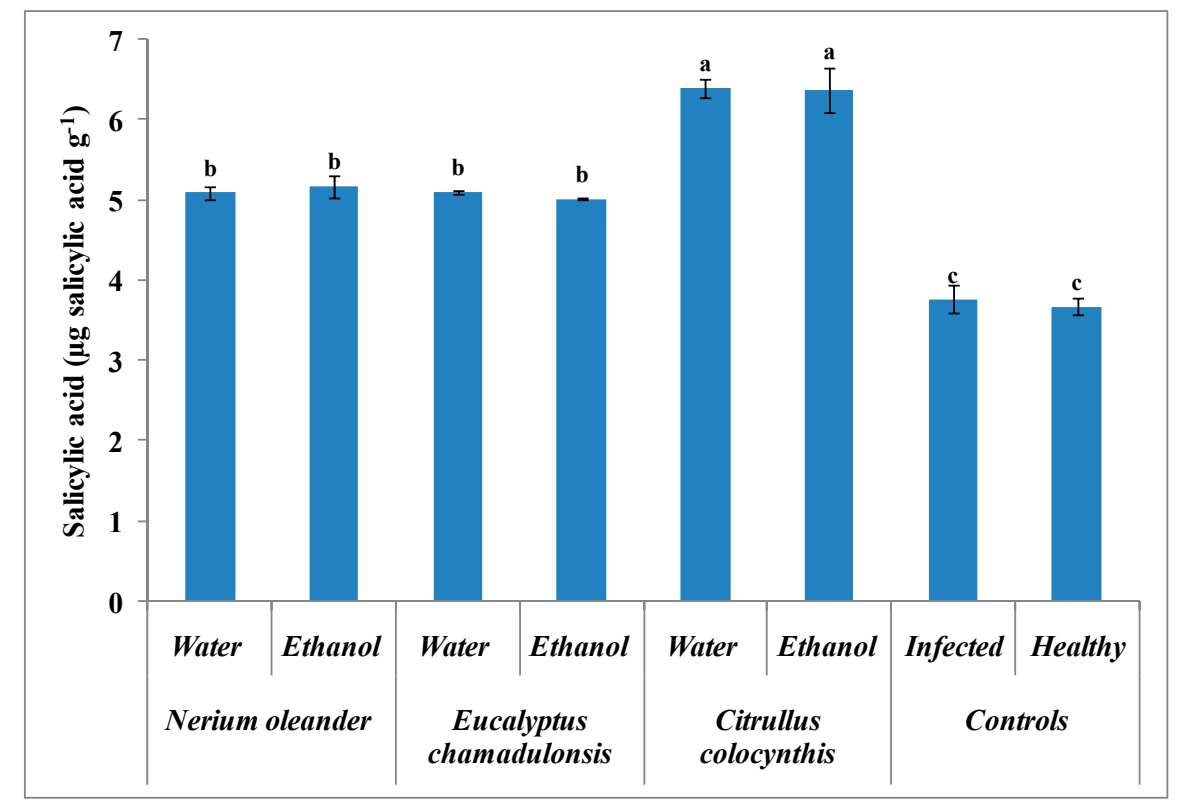

Figure 3. Effect of $15 \%$ concentrations of plant extracts of Nerium oleander, Eucalyptus chamadulonsis and Citrullus colocynthis on salicylic content of 'Super Marmande' tomato after 7 days of treatment with the extracts and inoculated with Xanthomonas axonopodis pv. vesicatoria PHYXV3. Four replicates were used for each treatment. Columns with the same letters are not significantly different according to Fisher's protected least significant difference at $p \leq 0.05$. 


\subsection{Effect of Plant Extracts on Peroxidase (PO)}

Peroxidase (PO) activity significantly increased in infected plants treated with extracts of all species except Nerium oleander (Figure 4). C. colocynthis extract caused the most increase in PO activity followed by E. chamadulonsis. Values for C. colocynthis were 6.9 and 6.25 Au per mg protein for water and ethanol extraction, respectively. The results agree with prior studies [45]. The results suggested that the plant extracts promoted an increase in defense- related peroxidase enzyme activity. Several investigators have reported that enhanced peroxidase activity was associated with plant defense against fungal, bacterial and viral pathogens [46].

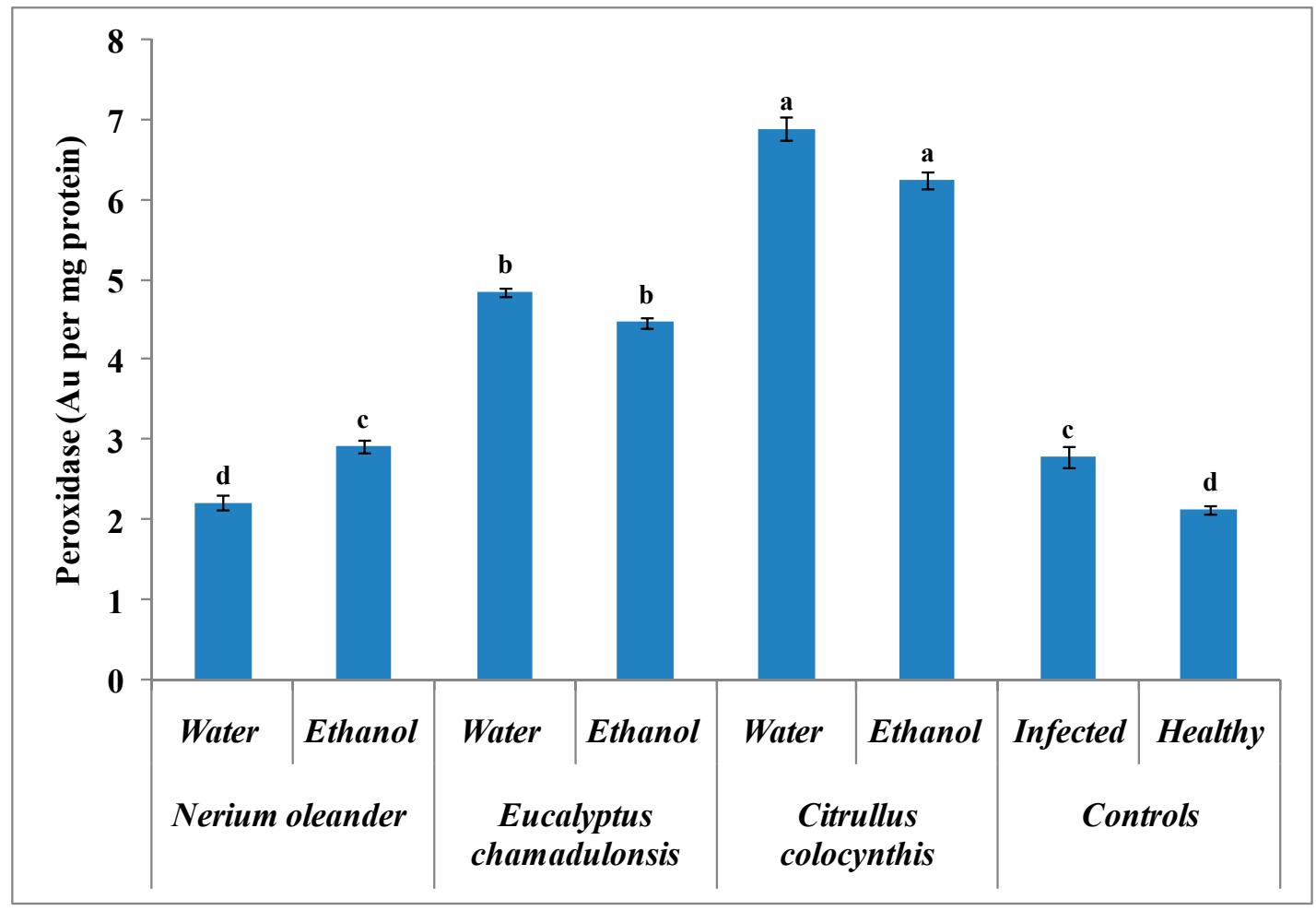

Figure 4. Effect of $15 \%$ concentrations of plant extracts of Nerium oleander, Eucalyptus chamadulonsis and Citrullus colocynthis on peroxidase activity as absorbance units ( $\mathrm{Au}$ ) per mg protein of 'Super Marmande' tomato after 7 days of treatment with the extracts and inoculated with Xanthomonas axonopodis pv. vesicatoria PHYXV3. Four replicates were used for each treatment. Columns with the same letters are not significantly different according to Fisher's protected least significant difference at $p \leq 0.05$.

\subsection{Effect of Plant Extract on Polyphenol Oxidase (PPO)}

In most cases, PPO activity showed no significant difference between infected tomato plants versus extract-treated plants using N. oleander and C. colocynthis extracts (Figure 5). The highest PPO activity was obtained following applications of E. chamadulonsis extracts 7 days post-application (1.25 and $1.6 \mathrm{~nm} \mathrm{mg}^{-1}$ protein for water and ethanol, respectively). Such results agree with other investigations $[40,46]$. The importance of PPO activity in disease resistance probably stems from its property to oxidize phenolic compounds to quinines, which are frequently more toxic to pathogens than the original phenol [46]. In addition, Draz et al. [39] mentioned that biochemical analyses proved a significant increase in the plant contents of total phenolics and oxidative enzymes activities (PPO and POX) after treated with certain plant extracts. 


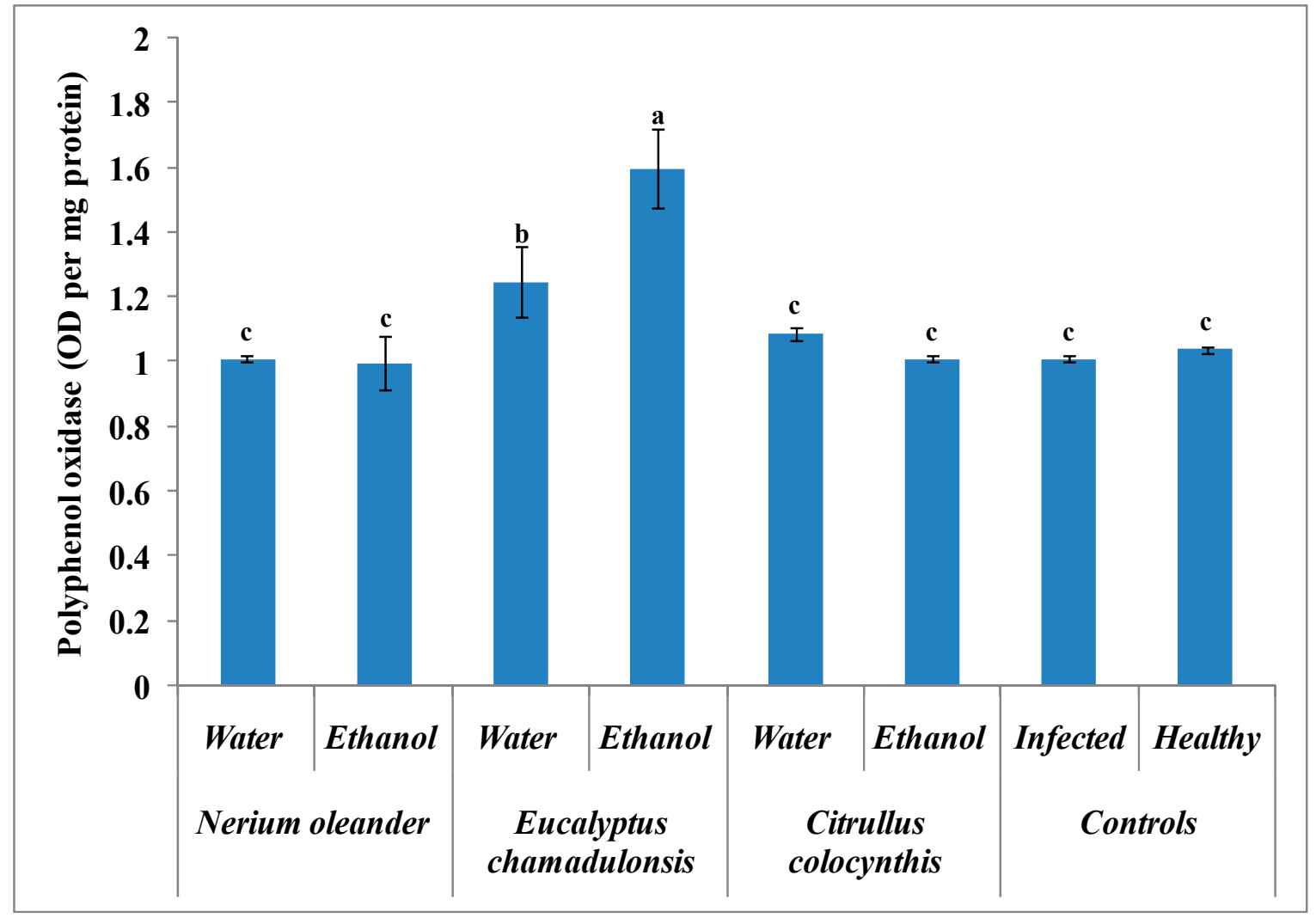

Figure 5. Effect of 15\% concentrations of plant extracts of Nerium oleander, Eucalyptus chamadulonsis and Citrullus colocynthis on polyphenol oxidase activity as optical density (OD) per mg protein of 'Super Marmande' tomato after 7 days of treatment with the extracts and inoculated with Xanthomonas axonopodis pv. vesicatoria PHYXV3. Four replicates were used for each treatment. Columns with the same letters are not significantly different according to Fisher's protected least significant difference at $p \leq 0.05$.

\section{Conclusions}

The antibacterial activity of aqueous and ethanol extracts of N. oleander, E. chamadulonsis and C. colocynthis plants were tested against Xanthomonas axonopodis pv. vesicatoria in vitro and inoculated plants in vivo. In in vitro tests, the highest antibacterial activity was achieved by extracts of C. colocynthis, followed by $N$. oleander and then E. chamadulonsis. Application of the extracts to tomato plants significantly reduced disease severity and increased shoot weight of 'Super Marmande' tomato plants. Overall, plant extracts significantly increased total phenol and salicylic acid content treated plants compared to healthy or infected ones. In addition, C. colocynthis and E. chamadulonsis significantly increased peroxidase activity while only E. chamadulonsis increased polyphenol oxidase. Thus, alternative means for controlling plant disease-such as plant extracts-may be able to replace or reduce the use of bactericides. Leaf extracts of these species showed promising antibacterial activity against the causal agent of tomato bacterial spot and could become a part of an integrated pest management program for controlling the disease.

Author Contributions: K.A.M.A.-E. conceived the research idea. N.M.A. and A.W.M.A. helped to collect the data. S.R.R. and K.Y. analyzed the data and wrote the study. All authors have read and agreed to the published version of the manuscript.

Funding: This research received no external funding.

Conflicts of Interest: The authors declare no conflicts of interest. 


\section{References}

1. FAOSTAT. Available online: http://www.fao.org/faostat/en/\#data/QC (accessed on 25 March 2020).

2. El-Hendawy, H.H.; Osman, M.E.; Sorour, N.M. Biological control of bacterial spot of tomato caused by Xanthomonas campestris pv. vesicatoria by Rahnella aquatilis. Microbiol. Res. 2005, 160, 343-352. [CrossRef] [PubMed]

3. Abo-Elyousr, K.A.M.; El-Hendawy, H.H. Integration of Pseudomonas fluorescens and acibenzolar-S-methyl to control bacterial spot disease of tomato. Crop Prot. 2008, 27, 1118-1124. [CrossRef]

4. Vallad, G.E.; Pernezny, K.L.; Balogh, B.; Wen, A.; Figueiredo, J.F.L.; Jones, J.B.; Momol, T.; Muchovej, R.; Havranek, N.; Abdallah, N.; et al. Comparison of kasugamycin to traditional bactericides for the management of bacterial spot on tomato. Hortscience 2010, 45, 1834-1840. [CrossRef]

5. Janse, J. Prevention and control of bacterial pathogens and diseases. In Phytobacteriol Principles Practice; CABI Publishing: Wallingford, UK, 2005; p. 360.

6. Youssef, K.; Hashim, A.F.; Margarita, R.; Alghuthaymi, M.A.; Abd-Elsalam, K.A. Fungicidal efficacy of chemically-produced copper nanoparticles against Penicillium digitatum and Fusarium solani on citrus fruit. Philipp. Agric. Sci. 2017, 100, 69-78.

7. Hussien, A.; Ahmed, Y.; Al-Essawy, A.; Youssef, K. Evaluation of different salt-amended electrolysed water to control postharvest moulds of citrus. Trop. Plant Pathol. 2018, 43, 10-20. [CrossRef]

8. Youssef, K.; de Oliveira, A.G.; Tischer, C.A.; Hussain, I.; Roberto, S.R. Synergistic effect of a novel chitosan/silica nanocomposites-based formulation against gray mold of table grapes and its possible mode of action. Int. J. Biol. Macromol. 2019, 141, 247-258. [CrossRef] [PubMed]

9. Kagale, S.T.; Marimuthu, T.; Thaynmanavan, P.; Nandakumar, P.; Samiyappan, R. Antimicrobial activity and induction of systemic resistance in rice by leaf extract of Datura metel against Rhizoctonia solani and Xanthomona soryzae pv. oryzae. Physiol. Mol. Plant Pathol. 2004, 65, 91-100. [CrossRef]

10. Balestra, G.M.; Heydari, A.D.; Ceccarelli, E.O.; Quattrucci, A. Antibacterial effect of Allium sativum and Ficus carica extracts on tomato bacterial pathogens. Crop Prot. 2009, 28, 807-811. [CrossRef]

11. Hassan, M.A.E.; Bereika, M.F.F.; Abo-Elnaga, H.I.G.; Sallam, M.A.A. Management of potato bacterial wilt using plant extracts, essential oils, antagonistic bacteria and resistance chemical inducers. Assiut J. Agric. Sci. 2008, 39, 141-159.

12. Abo-Elyousr, K.A.M.; Asran, M.R. Antibacterial activity of certain plant extracts against bacterial wilt of tomato. Arch. Phytopathol. Plant Prot. 2009, 42, 573-578. [CrossRef]

13. Hostettmann, K.; Wolfender, J.L. The search for biologically active secondary metabolites. Pestic. Sci. 1997, 51, 471-482. [CrossRef]

14. Mohana, D.C.; Raveesha, K.A. Anti-bacterial activity of Caesalpinia coriaria (Jacq.) Willd. against plantpathogenic Xanthomonas pathovars: An eco-friendly approach. J. Agric. Technol. 2006, 2, 317-327.

15. Bagy, H.M.M.; Abo-Elyousr, K.A.M. Antibacterial activity of some essential oils on bacterial spot disease of tomato plant caused by Xanthomonas axonopodis pv. vesicatoria. Int. J. Phytopathol. 2019, 8, 53-61. [CrossRef]

16. Joseph, B.M.; Darand, A.; Kumar, V. Bioefficacy of plant extracts to control Fusarium solani f.sp. melangenae incitant of brinjal wilt. Glob. J. Biotechnol. Biochem. 2008, 3, 56-59.

17. Khan, R.; Barira, I.; Mohd, A.; Shazi, S.; Anis, A.; Manazir, A.; Mashiatullah, S.; Asad, U.K. Antimicrobial activity of five herbal extracts against multidrug resistant (MDR) strains of bacteria and fungus of clinical origin. Molecules 2009, 14, 586-597. [CrossRef]

18. Salem, E.A.; Youssef, K.; Sanzani, S.M. Evaluation of alternative means to control postharvest Rhizopus rot of peaches. Sci. Hortic. 2016, 198, 86-90. [CrossRef]

19. Gurjar, S.M.; Shahid, A.; Masood, A.; Kangabam, S.S. Efficacy of plant extracts in plant disease management. Agric. Sci. 2012, 3, 425-433. [CrossRef]

20. Zahid, N.Z.; Abbasi, N.A.; Hafiz, A.I.; Hussain, A.; Ahmad, Z. Antifungal activity of localfennel (Foeniculum vulgare Mill) extracts to growth responses of some soil diseases. Afr. J. Microbiol. Res. 2012, 6, 46-51.

21. Kuc, J. Induced immunity to plant diseases. Bioscience 1982, 32, 854-860.

22. Fallanaj, F.; Sanzani, S.M.; Youssef, K.; Zavanella, C.; Salerno, M.G.; Ippolito, A. A new perspective in controlling postharvest citrus rots: The use of electrolyzed water. Acta Hortic. 2015, 1065, 1599-1606. [CrossRef] 
23. Srivastava, S.; Singh, V.P.; Kumar, R.; Srivastava, M.; Sinha, A.; Simon, S. In vitro evaluation of Carbendazim $50 \% \mathrm{WP}$, antagonists and botanicals against Fusarium oxysporum f.sp. psidii associated with rhizosphere soil of guava. Asian J. Plant Pathol. 2011, 5, 46-53. [CrossRef]

24. Geetha, H.M.; Shetty, H.S. Induction of resistance in pearl millet against mildew disease caused by Sclerospora graminicola using benzothiadiazole, calcium chloride and hydrogen peroxide-A comparative evaluation. Crop Prot. 2002, 21, 601-610. [CrossRef]

25. Hassan, M.E.M.; Abd-El-Rahman, S.S.; El-Abbasi, I.H.; Mikhail, M.S. Change in peroxidase activity due to resistance induced against faba bean chocolate spot disease. Egypt. J. Phytopathol. 2007, 35, 35-48.

26. Khan, W.; Prithiviraj, B.; Smith, D.L. Phytosynthetic response of corn and soybean to foliar application of salicylates. Plant Physiol. 2003, 160, 485-493. [CrossRef]

27. Oliveira, C.M.; Ferreira, A.C.S.; de Freitas, V.; Silva, A.M. Oxidation mechanisms occurring in wines. Food Res. Int. 2011, 44, 1115-1126. [CrossRef]

28. Abd-Rabboh, M.S.; El Shennawy, M.Z. Effect of some plant extracts on sugar beet powdery mildew. Egypt. J. Phytopathol. 2016, 44, 49-56.

29. Hassan, M.A.E.; Abo-Elyours, K.A.M. Activation of tomato plant defence responses against bacterial wilt caused by Ralstonia solanacearum using DL-3-aminobutyricacid (BABA). Eur. J. Plant Pathol. 2013, 146, 145-157. [CrossRef]

30. Abbasi, P.A.; Al-Dahmani, J.; Sahin, F.; Hoitink, H.A.J.; Miller, S.A. Effect of compost amendments on disease severity and yield of tomato in conventional and organic production systems. Plant Dis. 2002, 86, 156-161. [CrossRef]

31. Rapp, A.; Ziegler, A. Bestimmungder Phenolcarbonsaurein Rebblattern Weintraubeund Weinmittels Polamyid-Dunnschicht Chromatographie. Vitis 1973, 12, 226-236.

32. Sahin, F.; Gulluce, M.; Daferera, D.; Sokmen, A.; Sokmen, M.; Polissiou, M.; Agar, G.; Ozer, H. Biological activities of the essential oils and methanol extract of Origanum vulgares sp. vulgare in the Eastern Anatolia region of Turkey. Food Control 2004, 15, 549-557. [CrossRef]

33. Dat, J.F.; Foyer, C.H.; Scott, I.M. Changes in salicylic acid and antioxidants during induced thermo tolerance in mustard seedling. Plant Physiol. 1998, 118, 1455-1461. [CrossRef] [PubMed]

34. Bradford, M. A rapid and sensitive method for the quantitation of Microgram quantities of protein utilizing the principle of protein dye binding. Anal. Biochem. 1976, 72, 248-250. [CrossRef]

35. Putter, J. Peroxidase. In Methoden der Enzymatischen Analyses; Bergmeyer, H.U., Ed.; Verlag Chemie: Weinheim, Germany, 1974; p. 725.

36. Batra, G.K.; Kuhn, C.W. Polyphenoloxidase and peroxidase activities associated with acquired resistance and it inhibition by 2-thiouracilin virus infected soybean. Physiol. Plant Pathol. 1975, 5, 239-248. [CrossRef]

37. Hashim, A.F.; Youssef, K.; Abd-Elsalam, K.A. Ecofriendly nanomaterials for controlling gray mold of table grapes and maintaining postharvest quality. Eur. J. Plant Pathol. 2019, 154, 377-388. [CrossRef]

38. Rahman, M.M.; Gray, A.I. A benzoisofuranone derivative and carbazole alkaloids from Murraya koenigii and their antimicrobial activity. Phytochemstry 2005, 66, 1601-1606. [CrossRef]

39. Draz, I.S.; Amal, A.E.; Abdelnaser, A.E.; Hassan, M.E.; Abdel-Wahab, A.I. Application of plant extracts as inducers to challenge leaf rust of wheat. Egypt. J. Biol. Pest Control 2019, 29, 6. [CrossRef]

40. Hassan, M.A.E.; Bereika, M.F.F.; Abo-Elnaga, H.I.G.; Sallam, M.A.A. Direct Antimicrobial Activity and Induction of systemic resistance in potato plants against bacterial wilt disease by plant extracts. Plant Pathol. J. 2009, 24, 352-360. [CrossRef]

41. Abo-Elyousr, K.A.M.; Hussein, M.A.M.; Allam, A.; Hassan, M. Enhanced onion resistance against stemphylium leaf blight disease, caused by Stemphylium vesicarium, by di-potassium phosphate and benzothiadiazole treatments. Plant Pathol. J. 2008, 24, 171-177.

42. De Meyer, G.; Capieau, K.; Audenaert, K.; Buchala, A.; Métraux, J.P.; Hofte, M. Nanogram amounts of salicylic acid produced by the Rhizobacterium pseudomonas aeruginosa 7NSK2 activate the systemic acquired resistance pathway in Bean. Mol. Plant Microbe Interact. 1999, 12, 450-458. [CrossRef]

43. Zimmerli, L.; Jakab, G.; Metraux, J.P.; Mauch-Mani, B. Potentiation of pathogen-Specific defense mechanisms in Arabidopsis by $\beta$-Aminobutyric acid. Proc. Natl. Acad. Sci. USA 2000, 97, 12920-12925. [CrossRef]

44. Zimmerli, L.; Metraux, J.P.; Mauch-Mani, B. Beta-Aminobutyric acid-induced protection of Arabidopsis against the necrotrophic fungus Botrytis cinerea. Plant Physiol. 2001, 126, 517-523. [CrossRef] [PubMed] 
45. Seleim, M.A.A.; Abo-Elyousr, K.A.M.; Mohamed, A.A.; Al-Marzoky, H.A. Peroxidase and polyphenoloxidase activities as biochemical markers for biocontrol efficacy in the control of tomato bacterial wilt. J. Plant. Physiol. Pathol. 2014, 2, 2-8. [CrossRef]

46. Safdarpour, F.; Khodakaramain, G. Endophytic bacteria suppress bacterial wilt of tomato caused by Ralstonia solanacearum and Activate defense-related metabolites. Biol. J. Microorg. 2018, 6, 39-52.

(C) 2020 by the authors. Licensee MDPI, Basel, Switzerland. This article is an open access article distributed under the terms and conditions of the Creative Commons Attribution (CC BY) license (http://creativecommons.org/licenses/by/4.0/). 